\title{
Hospitalizations for Ambulatory Care Sensitive Conditions in Pinheiro - Maranhão
}

\author{
Beatriz Ferreira Feitosa*, Vitor da Cunha Stoco, Amanda Cristina dos Santos, Taynah Calixto \\ Martins, Felipe Sávio Cardoso Teles Monteiro and DéboraLuana Ribeiro Pessoa \\ Federal University of Maranhão, Medical School, Pinheiro, Brazil
}

*Corresponding author: Beatriz Ferreira Feitosa, Federal University of Maranhão, Medical Course, Pinheiro, Maranhão, Brazil

\section{ARTICLE INFO}

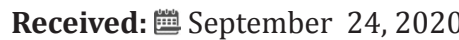

Published: 幽 October 06, 2020

Citation: Beatriz Ferreira Feitosa, Vitor da Cunha Stoco, Amanda Cristina dos Santos, Taynah Calixto Martins, Felipe Sávio Cardoso Teles Monteiro, Débora Luana Ribeiro Pessoa. Hospitalizations for Ambulatory Care Sensitive Conditions in Pinheiro - Maranhão. Biomed J Sci \& Tech Res 31(1)-2020. BJSTR. MS.ID.005031.

Keywords: Primary Health Care; Hospitalization; Quality of Health Care; Family Health Strategy

\section{ABSTRACT}

Objective: to describe hospitalizations for Ambulatory Care Sensitive Conditions (ACSC) in the municipality of Pinheiro - MA. Methods: a descriptive study whose data source was provided by the Unified Health System Hospital Information System (SIH / SUS) from 2008 to 2018. Results: the rate of ACSC in this municipality was $26.1 \%$, corresponding to 14.104 hospitalizations; the five most common diagnoses were bacterial pneumonia, infectious gastroenteritis, inflammatory disease of female organs, kidney and urinary tract infection, and heart failure; there were 698 deaths from ACSC, representing 50.2\% of all deaths from hospitalizations; ACSCs consumed R $\$ 7.976 .062,43$, corresponding to $24.0 \%$ of total hospitalization expenses in the municipality. Conclusion: the high occurrence of ACSC in Pinheiro - MA points to the need for further investigations on possible factors that are influencing the high rates of these hospitalizations in the studied region.

Abbreviations: PHC: Primary Health Care; WHO: World Health Organization; ESF: Family Health Strategy; RAS: Health Care Networks; ICSAP: Conditions Sensitive to Primary Care; ACSC: Clinic Care Sensitive Conditions; GDP: Gross Domestic Product; HDI: Human Development Index; UBS: Basic Health Units; CNES: National Registry of Health Establishments; SIH-SUS: Hospital Information System AIH: Hospitalization Authorization

\section{Introduction}

The Unified Health System of Brazil has as its entry point Primary Health Care (PHC), a care model recommended by the World Health Organization (WHO) to expand health care and ensure actions to promote and prevent diseases [1]. From 2006, with the National Primary Care Policy, the Family Health Strategy (ESF) was defined as fundamental for the reorganization, expansion and qualification of primary care. In addition to health promotion and protection, PHC must guarantee universal and continuous access, be resolutive and order as Health Care Networks (RAS) [2]. Considering that a PHC deficiency compromises the effectiveness of the other levels of care [3] in addition to being prioritized for reducing costs and improving health systems [4] it becomes necessary to evaluate and monitor the actions adopted by the model. One of the indicators used to assess the quality of PHC is the analysis of Hospitalizations for Conditions Sensitive to Primary Care (ICSAP), composed of health problems for which effective management in primary care reduces the risk of unnecessary hospitalizations [5]. Known internationally as an Outpatient Clinic Care Sensitive Conditions (ACSC), this indicator emerged in the 1980s in the United States and began to be used as an assessment tool in the 1990s in other countries, such as Canada and Spain [6].

In Brazil, the ICSAP relationship was created by the Ministry of Health in 2008 after the survey and review of the group of diseases listed by other countries, as a way of adapting to the Brazilian reality. Some aspects were considered when choosing the diseases that would make up the national list, such as ease of diagnosis and the ability to resolve and intervene in primary health in relation to these pathologies, thus avoiding hospitalization [7]. The Ministry of Health officially published the Brazilian list of ICSAP through Ordinance No. 221, on April 17, 2008, with 74 diagnoses found 
in 19 groups of causes of hospitalizations, classified according to the Tenth International Statistical Classification of Diseases and Health-Related Problems (ICD-10): preventable diseases by immunization and conditions, infectious gastroenteritis and complications, anemia, nutritional deficiencies, abnormalities in the nose and throat, bacterial pneumonia, asthma, lung disease, hypertension, angina, heart failure, cerebrovascular diseases, diabetes mellitus, epilepsies, kidney and urinary tract infections, skin and subcutaneous tissue disorders, inflammatory diseases of the female pelvic organs, gastrointestinal ulcer and diseases related to prenatal and childbirth [8]. The principle of the ICSAP indicator is that effective and resolutive primary care reflects the decrease in hospitalizations for specific causes [9]. High rates of ICSAP are able to identify more vulnerable groups or populations and show deficiencies in the health system, such as low coverage, ineffective resolution. and failure in prevention and early diagnosis $[10,11]$.

Data generated by this indicator can be used in the construction of objective analyzes on the health situation of municipalities and regions, causing interventions based on evidence and directed to the needs of the population [12]. In addition to FHS coverage, socioeconomic conditions influence HACSC rates [13]. The North and Northeast regions have both the highest HACSC rates in the country and the highest rates of illiteracy and infant mortality, the lowest gross domestic product (GDP) per capita and lower coverage of sanitary sewage [14]. Inserted in this reality, the municipality of Pinheiro - MA is the 12th largest city in the state in terms of population and the 1st in the Baixada Maranhense and has a human development index (HDI) of 0.637 [15]. Considering that ICSAP is a preventable occurrence, it is possible to assume that the indicator reflects the quality of care in primary care, as it is a way of indirect assessment of access, coverage and performance in a region [16]. When carrying out a evaluation of the profile of Hospitalizations for Conditions Sensitive to Primary Care (ICSAP) in the city of Pinheiro - MA it is possible to detect the effectiveness of the coverage of primary care in the municipality and direct interventions to improve and qualify public health. There are studies in the Brazilian scientific literature regarding HACSC in municipalities in Maranhão, $[17,18]$ and there are no studies published on this indicator in the municipality of Pinheiro up to that time. Thus, this study seeks to contribute to the recognition of problems in the local public health network and to the increase in the organization and coordination of municipal health care. The aim of this study, therefore, was to describe the profile of HACSC in Pinheiro, Maranhão, from 2008 to 2018, as a proposal to provide information and determine the impact of these hospitalizations on PHC care quality in the region.

\section{Methods}

This is a descriptive study on hospitalizations for conditions sensitive to primary care of patients living in the municipality of Pinheiro, Maranhão, from 2008 to 2018. The municipality has a population of 78,162 inhabitants and a human development index (HDI) of 0.637, occupying the position 3.357th in the ranking among Brazilian municipalities according to the 2010 demographic census.15 It is the hub of the Macroregion of Saúde de Pinheiro, which comprises 28 municipalities and corresponds to a population of 627,099 inhabitants. It has 18 Basic Health Units (UBS) and 3 hospital units registered in the National Registry of Health Establishments (CNES), totaling 256 available beds [19]. Coverage by the FHS increased from $69.82 \%$ to $79.58 \%$ between 2008 and 2018 [20]. Data regarding hospital admissions were collected in the Hospital Information System (SIH-SUS) of the SUS Information and Informatics Department (Datasus), using the Hospitalization Authorization (AIH). The main diagnosis of $\mathrm{AIH}$ was defined as the cause of hospitalization according to the ICD10. ICSAP were classified based on the list defined by Ordinance No. 221, of the Ministry of Health, of April 17, 20088 and the other diagnoses as non-ICSAP hospitalizations. Data were collected on the variables sex, age, race / color, number of deaths and amounts spent on hospitalizations.

The data were tabulated using the Microsoft Excel 2019® program. The ICSAP were analyzed by diagnostic groups and according to the collected variables, with frequencies and percentages estimated for the period 2008-2018. The proportions of HACSC were calculated by the total number of general admissions and the number of deaths caused by HACSC by the number of deaths from general admissions. It was also calculated the amounts spent in reais ( $\mathrm{R} \$$ ) with ICSAP, the proportion of expenditures with ICSAP for the total expenses with general hospitalizations and the ICSAP coefficients per 1,000 inhabitants for the years of the study. This study used secondary data in the public and non-nominal domain, and the presentation of the project to the Research Ethics Committee was waived. However, all ethical aspects regarding research with human beings were respected, according to the Resolution of the National Health Council No. 466, of December 12, 2012.

\section{Results}

In the period from 2008 to 2018, 54,017 hospital admissions of patients residing in Pinheiro - MA were registered. Of these, 14,104 hospitalizations were due to ICSAP, corresponding to $26.1 \%$ of the total hospitalizations and a coefficient of 180.4 hospitalizations / thousand inhabitants. There was an $89 \%$ increase in cases of HACSC from 2008 (995 cases) to 2018 (1881 cases), with fluctuations in the percentage rates referring to HACSC during the period studied. The number of non-ICSAP admissions exceeded the number of ICSAP in all years. Between 2008 and 2018 there was an increase in the coefficient per thousand inhabitants from 12.7 to 24.1 hospitalizations / thousand inhabitants (Table 1). Among the groups of causes, the five most frequent were bacterial pneumonia (20.9\%), infectious gastroenteritis (14.1\%), inflammatory disease of the female pelvic organs $(12.2 \%)$, kidney infection and urinary tract $(7,6 \%)$ and heart failure $(6.4 \%)$, which together accounted 
for $61.2 \%$ of ICASP. The five least frequent groups were anemia $(0.2 \%)$, diseases preventable by immunization and sensitive conditions $(0.5 \%)$, nutritional deficiencies $(0.6 \%)$, angina $(1.1 \%)$ and epilepsy $(1,2 \%)$ (Tables 2a \& 2b). Regarding the distribution of HACSC by age group, adults (20 to 59 years old) represented $37.8 \%$ of HACSC, followed by the elderly ( $\geq 60$ years old) (28.4\%), children ( $<1$ to 9 years old) ( $27.2 \%$ ) and adolescents (10 to 19 years old) (6.6\%). The age group of 20-29 years was the only one that showed a reduction (-7.8\%) of HACSC between 2008 and 2018 (Tables 2a \& 2b).

Table 1: Distribution (absolute and percentage values) and coefficient per thousand inhabitants of hospitalizations sensitive to primary care (ICSAP) according to the year of hospitalization of patients residing in the municipality of Pinheiro, Maranhão, 2008 to 2018 .

\begin{tabular}{|c|c|c|c|c|c|}
\hline \multirow{2}{*}{ Hospitalizations } & \multicolumn{2}{|c|}{ Not-ICSAPa } & \multicolumn{2}{|c|}{ ICSAP } & \multirow{2}{*}{$\begin{array}{c}\text { Coefficient of ICSAP/ } \\
\text { mil hab. }\end{array}$} \\
\hline & $\mathbf{N}$ & $\%$ & $\mathbf{N}$ & $\%$ & \\
\hline 2008 & 3.100 & 75,7 & 995 & 24,3 & 12,7 \\
\hline 2009 & 3.329 & 73,6 & 1.197 & 26,4 & 15,3 \\
\hline 2010 & 3.361 & 70,7 & 1.395 & 29,3 & 17,8 \\
\hline 2011 & 3.206 & 72,8 & 1.195 & 27,2 & 15,3 \\
\hline 2012 & 2.700 & 74,5 & 926 & 25,5 & 11,8 \\
\hline 2013 & 3.377 & 72,0 & 1.315 & 28,0 & 16,8 \\
\hline 2014 & 3.530 & 75,1 & 1.173 & 24,9 & 15,0 \\
\hline 2015 & 3.746 & 78,9 & 1.000 & 21,1 & 12,8 \\
\hline 2016 & 3.945 & 75,1 & 1.311 & 24,9 & 16,8 \\
\hline 2017 & 4.940 & 74,2 & 1.716 & 25,8 & 22,0 \\
\hline 2018 & 4.679 & 71,3 & 1.881 & 28,7 & 24,1 \\
\hline Total & 39.913 & 73,9 & 14.104 & 26,1 & 180,4 \\
\hline
\end{tabular}

Note: a) Non-ICSAP: total in hospitalizations, except hospitalizations for causes sensitive to primary care Source: SUS Hospital Information System (SIH / SUS / Datasus / MS).

Table 2a: Distribution (percentage values) of hospitalizations for conditions sensitive to primary care (ACSC) according to groups of causes of hospitalizations and age group of patients living in the city of Pinheiro, Maranhão, 2008 to 2018.

\begin{tabular}{|c|c|c|c|c|c|c|c|c|c|c|c|c|c|}
\hline \multirow{2}{*}{ ICSAP } & \multicolumn{13}{|c|}{ Age group (in years) } \\
\hline & $<1$ & $1-4$ & $5-9$ & $10-14$ & $15-19$ & $20-29$ & $30-39$ & $40-49$ & $50-59$ & $60-69$ & 70-79 & 80 e + & Total \\
\hline $\begin{array}{l}\text { Immunizationpreventable } \\
\text { diseases and sensitive } \\
\text { conditions }\end{array}$ & 0,2 & 0,4 & 2,0 & 1,4 & 0,9 & 0,3 & 1,0 & 0,9 & 0,4 & 0,2 & 0,0 & 0,0 & 0,5 \\
\hline $\begin{array}{l}\text { Infectious gastroenteritis } \\
\text { and complications }\end{array}$ & 21,6 & 32,1 & 27,0 & 16,1 & 8,6 & 5,2 & 7,6 & 12,7 & 10,2 & 9,6 & 9,9 & 10,1 & 14,1 \\
\hline Anemia & 0,0 & 0,1 & 0,6 & 0,0 & 0,7 & 0,1 & 0,2 & 0,1 & 0,5 & 0,2 & 0,3 & 0,0 & 0,2 \\
\hline Nutritional deficiencies & 2,5 & 0,4 & 1,2 & 0,6 & 0,3 & 0,3 & 0,3 & 0,4 & 0,5 & 0,3 & 0,4 & 0,9 & 0,6 \\
\hline $\begin{array}{l}\text { Ear, nose and throat } \\
\text { infections }\end{array}$ & 1,3 & 3,0 & 3,1 & 2,0 & 0,9 & 2,5 & 1,8 & 0,4 & 0,1 & 0,2 & 0,1 & 0,2 & 1,4 \\
\hline Bacterial pneumonia & 38,4 & 41,8 & 31,0 & 30,7 & 13,4 & 5,8 & 11,4 & 16,4 & 13,3 & 14,9 & 17,3 & 22,5 & 20,9 \\
\hline Asthma & 2,1 & 5,0 & 9,2 & 4,8 & 0,5 & 0,3 & 0,8 & 0,9 & 0,9 & 0,7 & 1,4 & 0,7 & 1,9 \\
\hline Lung diseases & 17,7 & 5,4 & 3,5 & 2,5 & 0,5 & 0,2 & 1,0 & 0,9 & 2,3 & 2,3 & 4,9 & 5,5 & 4,1 \\
\hline Hypertension & 0,0 & 0,0 & 0,3 & 0,3 & 0,5 & 0,4 & 1,0 & 3,5 & 6,1 & 5,3 & 6,3 & 4,1 & 2,3 \\
\hline Angina & 0,1 & 0,0 & 0,0 & 0,0 & 0,3 & 0,2 & 0,4 & 2,1 & 2,9 & 3,3 & 2,4 & 0,9 & 1,1 \\
\hline Cardiac insufficiency & 2,1 & 1,0 & 0,9 & 2,8 & 2,8 & 2,2 & 4,2 & 5,8 & 9,2 & 11,8 & 14,3 & 17,4 & 6,4 \\
\hline Cerebrovascular diseases & 0,1 & 0,0 & 0,2 & 0,0 & 0,7 & 0,9 & 1,2 & 7,5 & 12,5 & 15,1 & 15,2 & 15,1 & 5,9 \\
\hline Diabetes mellitus & 0,1 & 0,1 & 0,2 & 2,3 & 1,2 & 0,6 & 1,7 & 3,7 & 10,7 & 14,6 & 10,3 & 9,1 & 4,6 \\
\hline
\end{tabular}


Table 2b: Distribution (percentage values) of hospitalizations for conditions sensitive to primary care (ACSC) according to groups of causes of hospitalizations and age group of patients living in the municipality of Pinheiro, Maranhão, 2008 to 2018.

\begin{tabular}{|c|c|c|c|c|c|c|c|c|c|c|c|c|c|}
\hline \multirow{2}{*}{ ICSAP } & \multicolumn{13}{|c|}{ Age group (in years) } \\
\hline & $<1$ & $1-4$ & $5-9$ & 10-14 & $15-19$ & $20-29$ & $30-39$ & $40-49$ & $50-59$ & $60-69$ & 70-79 & $80 \mathrm{e}+$ & Total \\
\hline Epilepsies & 1,7 & 1,4 & 2,6 & 3,9 & 2,3 & 1,0 & 1,2 & 1,6 & 0,6 & 0,5 & 0,1 & 0,5 & 1,2 \\
\hline $\begin{array}{l}\text { Kidney and urinary tract } \\
\text { infection }\end{array}$ & 2,3 & 3,5 & 7,4 & 14,1 & 14,3 & 6,9 & 11,3 & 13,9 & 10,0 & 7,6 & 7,3 & 6,4 & 7,6 \\
\hline $\begin{array}{l}\text { Infection of skin and } \\
\text { subcutaneous tissue }\end{array}$ & 3,7 & 5,0 & 9,2 & 13,8 & 12,6 & 5,6 & 7,6 & 9,6 & 8,5 & 6,9 & 3,5 & 2,5 & 6,3 \\
\hline $\begin{array}{l}\text { Inflammatory disease of } \\
\text { female pelvic organs }\end{array}$ & 0,3 & 0,0 & 0,0 & 1,1 & 12,7 & 50,0 & 32,6 & 9,0 & 2,1 & 0,8 & 0,4 & 0,2 & 12,2 \\
\hline Gastrointestinal ulcer & 1,9 & 0,7 & 1,5 & 2,3 & 3,0 & 2,8 & 5,7 & 9,5 & 9,1 & 5,7 & 5,8 & 3,8 & 4,1 \\
\hline $\begin{array}{l}\text { Diseases related to prenatal } \\
\text { care and childbirth }\end{array}$ & 3,9 & 0,0 & 0,0 & 1,4 & 23,7 & 14,9 & 9,2 & 1,2 & 0,1 & 0,0 & 0,0 & 0,0 & 4,6 \\
\hline Total & 100,0 & 100,0 & 100,0 & 100,0 & 100,0 & 100,0 & 100,0 & 100,0 & 100,0 & 100,0 & 100,0 & 100,0 & 100,0 \\
\hline
\end{tabular}

The group of bacterial pneumonias had the highest percentage of HACSC in the age groups <1 year (38.4\%), 1-4 years $(41.8 \%)$, 5-9 (31.0\%) and 10-14 years (30.7\%); infectious gastroenteritis was the second largest diagnosis in these age groups. Considering adolescents aged 15-19, diseases related to childbirth and prenatal care accounted for $23.7 \%$ of HACSC. In adults aged 20-29 years and 30-39 years, inflammatory disease of female pelvic organs represented $50.0 \%$ and $32.6 \%$ of HACSC, respectively (Table $2 \mathrm{a}$ $\& 2 \mathrm{~b})$. The kidney and urinary tract infection group had high percentages of HACSC in the 10-19 and 30-59 age groups. Heart failure, cerebrovascular diseases and diabetes, on the other hand, had the highest percentage rates in patients over 50 years of age, with cerebrovascular diseases being the main cause of HACSC between 60-69 years (15.1\%) (Tables 2a \& 2b). Regarding gender, ACSCs were more common in females (57.4\%), with inflammatory disease of female pelvic organs (21.2\%), bacterial pneumonias $(18.5 \%)$ and infectious gastroenteritis (13.3\%) the most common causes of hospitalization in this group. In males, pneumonia, gastroenteritis and infection of skin and subcutaneous tissue represented $48.8 \%$ of HACSC (Table 3 ).

Table 3: Distribution (percentage values) of admissions for conditions sensitive to primary care (ICSAP) according to groups of causes of hospitalizations and sex of patients living in the municipality of Pinheiro, Maranhão, 2008 to 2018.

\begin{tabular}{|c|c|c|c|}
\hline \multirow{2}{*}{ ICSAP } & \multicolumn{3}{|c|}{ Gender (in years) } \\
\hline & Male & Female & Total \\
\hline Immunization preventable diseases and sensitive conditions & 0,6 & 0,4 & 0,5 \\
\hline Infectious gastroenteritis and complications & 15,2 & 13,3 & 14,1 \\
\hline Anemia & 0,3 & 0,1 & 0,2 \\
\hline Nutritional deficiencies & 0,8 & 0,5 & 0,6 \\
\hline Ear, nose and throat infections & 1,0 & 1,7 & 1,4 \\
\hline Bacterial pneumonia & 24,1 & 18,5 & 20,9 \\
\hline Asthma & 1,9 & 1,9 & 1,9 \\
\hline Lung diseases & 5,4 & 3,1 & 4,1 \\
\hline Hypertension & 2,5 & 2,2 & 2,3 \\
\hline Angina & 1,6 & 0,6 & 1,1 \\
\hline Cardiac insufficiency & 9,0 & 4,4 & 6,4 \\
\hline Cerebrovascular diseases & 7,1 & 5,0 & 5,9 \\
\hline Diabetes mellitus & 5,4 & 4,0 & 4,6 \\
\hline Epilepsies & 1,5 & 0,9 & 1,2 \\
\hline Kidney and urinary tract infection & 7,3 & 7,8 & 7,6 \\
\hline Infection of skin and subcutaneous tissue & 9,5 & 3,9 & 6,3 \\
\hline Inflammatory disease of female pelvic organs & 0,0 & 21,2 & 12,2 \\
\hline Gastrointestinal ulcer & 6,1 & 2,6 & 4,1 \\
\hline Diseases related to prenatal care and childbirth & 0,5 & 7,6 & 4,6 \\
\hline Total & 100,0 & 100,0 & 100,0 \\
\hline
\end{tabular}


The most registered race / color was brown (74.5\%), followed by yellow $(2.8 \%)$, white $(1.3 \%)$ and black $(0.9 \%)$. It is important to note that $20.5 \%$ of the AIH did not have the race / color informed by the patients and that there was no record of patients declared indigenous. 1,391 deaths were recorded in hospital admissions during the study period; of these, 698 deaths were due to ICSAP, representing $50.2 \%$ of the total. The number of deaths from HACSC was higher than the number of deaths from non-HACSC in the years 2008, 2010, 2011, 2013, 2017 and 2018 (Table 4). The five major causes of deaths from ACSC were cerebrovascular diseases (24.5\%), heart failure (23.2\%), bacterial pneumonia $(17.9 \%)$, diabetes (8.2\%) and gastrointestinal ulcer (6.9\%), respectively (Table 5). Total spending on hospitalizations for patients residing in Pinheiro - MA was R \$33,201,940.51; ICSAP expenses totaled R \$ 7,976,062.43, corresponding to $24.0 \%$ of the total. During the study period, the most expensive diagnoses were pneumonia (24.2\%), heart failure (13.0\%), inflammatory disease of the female pelvic organs $(9.6 \%)$, infectious gastroenteritis (7.9\%) and angina (7.4\%); together they represent $62 \%$ of the amount spent on ICSAP (Table 5).
Table 4: Number of deaths due to primary care-sensitive hospitalizations (ACSC) according to the year of hospitalization of patients living in the municipality of Pinheiro, Maranhão, 2008 to 2018 .

\begin{tabular}{|c|c|c|c|c|}
\hline \multirow{2}{*}{ № Deaths } & \multicolumn{2}{|c|}{ Not-ICSAPa $^{\mathbf{a}}$} & \multicolumn{2}{c|}{ ICSAP } \\
\cline { 2 - 5 } & $\mathbf{N}$ & $\mathbf{\%}$ & $\mathbf{N}$ & $\%$ \\
\hline 2008 & 23 & 40,4 & 34 & 59,6 \\
\hline 2009 & 46 & 51,1 & 44 & 48,9 \\
\hline 2010 & 45 & 45,9 & 53 & 54,1 \\
\hline 2011 & 40 & 40,0 & 60 & 60,0 \\
\hline 2012 & 58 & 58,0 & 42 & 42,0 \\
\hline 2013 & 55 & 45,1 & 67 & 54,9 \\
\hline 2014 & 57 & 54,8 & 47 & 45,2 \\
\hline 2015 & 69 & 58,0 & 50 & 42,0 \\
\hline 2016 & 90 & 50,3 & 89 & 49,7 \\
\hline 2017 & 100 & 50,0 & 100 & 50,0 \\
\hline 2018 & 110 & 49,5 & 112 & 50,5 \\
\hline Total & 693 & 49,8 & 698 & 50,2 \\
\hline
\end{tabular}

Table 5: Distribution of hospitalizations for conditions sensitive to primary care (ACSC) according to groups of causes of hospitalizations, number of deaths and amounts spent in reais (R \$) with patients living in the city of Pinheiro, Maranhão, 2008 to 2018.

\begin{tabular}{|c|c|c|c|c|}
\hline \multirow{2}{*}{ ICSAP } & \multicolumn{2}{|c|}{ Deaths } & \multicolumn{2}{|c|}{ Amounts spent ( $\mathrm{R} \$$ ) } \\
\hline & $\mathbf{N}$ & $\%$ & $\mathbf{N}$ & $\%$ \\
\hline Immunization preventable diseases and sensitive conditions & 3 & 0,4 & $33.570,45$ & 0,4 \\
\hline Infectious gastroenteritis and complications & 32 & 4,6 & $632.525,85$ & 7,9 \\
\hline Anemia & 2 & 0,3 & $8.505,01$ & 0,1 \\
\hline Nutritional deficiencies & 14 & 2,0 & $122.907,05$ & 1,5 \\
\hline Ear, nose and throat infections & 1 & 0,1 & $60.660,21$ & 0,8 \\
\hline Bacterial pneumonia & 125 & 17,9 & $1.929 .608,93$ & 24,2 \\
\hline Asthma & 2 & 0,3 & $133.055,37$ & 1,7 \\
\hline Lung diseases & 26 & 3,7 & $196.649,22$ & 2,5 \\
\hline Hypertension & 11 & 1,6 & $112.356,33$ & 1,4 \\
\hline Angina & 8 & 1,1 & $592.747,07$ & 7,4 \\
\hline Cardiac insufficiency & 162 & 23,2 & $1.040 .472,68$ & 13,0 \\
\hline Cerebrovascular diseases & 171 & 24,5 & $555.923,62$ & 7,0 \\
\hline Diabetes mellitus & 57 & 8,2 & $344.909,52$ & 4,3 \\
\hline Epilepsies & 4 & 0,6 & $72.973,16$ & 0,9 \\
\hline Kidney and urinary tract infection & 18 & 2,6 & $304.370,56$ & 3,8 \\
\hline Infection of skin and subcutaneous tissue & 3 & 0,4 & $434.519,66$ & 5,4 \\
\hline Inflammatory disease of female pelvic organs & 1 & 0,1 & $764.976,56$ & 9,6 \\
\hline Gastrointestinal ulcer & 48 & 6,9 & $379.102,46$ & 4,8 \\
\hline Diseases related to prenatal care and childbirth & 10 & 1,4 & $256.228,72$ & 3,2 \\
\hline Total & 698 & 100 & $7.976 .062,43$ & 100,0 \\
\hline
\end{tabular}




\section{Discussion}

Considering that the ICSAP are a reflection of the coverage and quality of care in PHC, it is expected that the resolving capacity of the FHS will impact the indexes of this indicator. The present study showed an overall increase in HACSC in the municipality of Pinheiro - MA between the years 2008 and 2018, although significant reductions were recorded between the years 2010 to 2015. The proportion of HACSC found (26.1\%) was higher than the result obtained in other Brazilian cities, such as São José do Rio Preto-SP, 12 Rio de Janeiro-RJ1 and Ceilândia-DF, 7 which showed a proportion of $18.7 \%, 19.68 \%$ and $15.9 \%$, respectively. However, the rate of ICSAP for Pinheiro is lower than that found in Brazil in 2006 (28.5\%) 21 and in the city of Divinópolis, Minas Gerais, between July and October 2011 (36.6\%) [16]. Despite the expansion of FHS coverage in the municipality between the years studied, there was an increase of $89 \%$ in ICSAP. Rodrigues-Bastos and collaborators, 22 Arruda and Costa6 and Sousa and collaborators [7] also found the same relationship between ICSAP and ESF coverage in their respective studies [21-24].

However, several Brazilian studies point to a trend towards stabilization or reduction in ACSC, mainly when associated with the growth of the population coverage of the FHS.1,3,5,11,23,24 In Florianópolis, Santa Catarina, between 2001 and 2011 there was a decrease in ICSAP about 3.0\% per year, accompanied by the $10.0 \%$ increase in coverage by the FHS in the period. 4 A similar situation was also found in São Luís, capital of Maranhão, where the FHS coverage increased from $18.24 \%$ in 2002 to $27.53 \%$ in 2012 , whereas the frequency of ICSAP decreased in the same period.18 In the state of Espírito Santo, between the years 2000 and 2014 there was a $28.79 \%$ reduction in ICSAP, excluding deliveries, at the same time, FHS coverage grew $151 \%$ in the region [13]. In view of the existing FHS coverage in Pinheiro - MA, it can be seen that the population's access to PHC is not sufficient to meet the demand for health in the region, since the present study found high rates of ACSC. Several factors may be related to this failure in PHC resolution, especially health determinants, such as sanitary conditions, educational level and per capita income, which directly interfere in the health-disease process [7]. Weakness in the management of human and financial resources it is also an obstacle to maintaining the quality and resolution of the PHC service, since the lack of qualified professionals or resources at the BHU presents a great risk for the evolution of the pathological process or uncontrolled condition, leading the patient to seek hospital service. and possibly progressing to hospitalization [5].

The most frequent diagnostic group was bacterial pneumonia (20.9\%), followed by infectious gastroenteritis (14.1\%), inflammatory disease of the female pelvic organ (12.2\%), kidney and urinary tract infection $(7,6 \%)$ and heart failure $(6.4 \%)$. These five groups were also found to be the main causes of HACSC in studies by Pazó and collaborators, 13 Mendonça and Albuquerque
[3] and Santos et al [5]. The high rate of HACSC due to inflammatory disease of female pelvic organs stands out, unlike other Brazilian studies that bring this cause as one of the least frequent $[3,25]$. The ACSCs in general prevailed in females (57.4\%), in agreement with other Brazilian studies, $[5,7,12,16,24]$ being the inflammatory disease of pelvic organs the main cause of hospitalization in this group (21.2\%). The 20 to 29 age group concentrated $50 \%$ of the cases in this diagnostic group, followed by patients between 30 and 39 years old (32.6\%). On the other hand, diseases related to childbirth and prenatal care, prevalent in females (7.6\%), were the main cause of HACSC among adolescents aged 15 to 19 years, a fact also observed by Sousa et al. 15 to 24 years. Rodrigues-Bastos et al22 found in their study that inflammatory diseases of Organs pelvic organs were the most frequent cause of ACSC in women aged 25 to 39 years and diseases related to childbirth and prenatal care were the second most frequent cause in women aged 10 to 24 years.

These results suggest the existence of flaws in PHC, which should be timely and decisive in relation to women's health, one of the priority axes within SUS. Pitilin et al [26] suggest that, in addition to the low coverage of the FHS and the disorganization of the health service, deficient access to social determinants, such as leisure, income and education, may contribute to the increase of ICSAP in this audience. The large number of ICSAP related to childbirth and prenatal care also suggests a compromise in the care provided to pregnant women, even with the expansion of actions related to prenatal care in the country [11]. Therefore, to reduce this indicator, periodic assessments should be carried out about the deficiencies present in health services associated with the assistance offered to women and the epidemiological profile of the female population assisted by the FHS. The age groups most affected by ICSAP in Pinheiro - MA were adults and the elderly, also pointed out by other authors $[5,12]$. However, this finding differs from studies that point to children and the elderly as the two most vulnerable populations affected by ICSAP. 7.13,18.25 Bacterial pneumonias were the main cause of ACSC in most age groups, especially in children. Some risk factors for the occurrence of these pathologies in children are reported in the literature, such as low birth weight and inadequate breastfeeding [14].

However, this does not explain the high proportions found in other age groups, requiring further studies on the epidemiological profile of children. pneumonia in the municipality. It is important to note that the increase in FHS coverage may be related to the increase in cases identified early and appropriate referral to hospitalization in necessary cases [18]. Infectious gastroenteritis and its complications are also associated with high rates of HACSC in children, as well as in other studies [5,7,12-14,25]. Despite the availability of low cost and complex therapeutic measures, gastroenteritis still prevails in the profile of Brazilian morbidity and mortality, especially in regions with a higher concentration of poverty, precarious socioeconomic conditions and deficient basic 
sanitation [22]. In 2010, only 49.3\% of households in Pinheiro - MA had adequate sanitary sewage.15 These data point to the need for policies effective public policies that improve the health conditions of the population, thus reducing the impact of these health problems. The groups heart failure, cerebrovascular diseases and diabetes prevailed in the elderly, as well as in the study by Sousa et al. in this age group, mainly due to heart failure, gastroenteritis, cerebrovascular diseases, diabetes and hypertension [27]. It is observed that the most prevalent causes in Pinheiro are chronic degenerative diseases associated with the aging process. In addition, the frailty of the elderly, the limitations of locomotion and transportation, inadequate nutrition and the absence of a caregiver are some of the factors that can lead to an increase in hospitalizations in the elderly [18].

A data that deserves to be highlighted is that $50.2 \%$ ( $\mathrm{n}=$ 698) of deaths that occurred during hospitalizations in the municipality were due to ACSC, that is, due to conditions that should not evolve to hospitalization. In Ceilândia - DF, there were 568 deaths due to ACSC between 2008 and 2012, the main causes being cerebrovascular diseases, diabetes mellitus, gastrointestinal ulcers and heart failure, 7 according to the causes found in this study. Analyzing the amounts spent on ICSAP, it can be seen that these hospitalizations consumed $24.0 \%$ of the total spent on general hospitalizations, which corresponds approximately to $\mathrm{R} \$$ 8 million reais paid by SUS. It is noteworthy here that the amounts paid for hospitalizations resulting from births (which represent a natural outcome of pregnancy) are added to the total amount spent on general hospitalizations. Thus, it is deduced that if births were excluded, the proportion of expenses with ICSAP would be higher. Other studies pointed out the magnitude of costs with ACSC, such as in the health region of São José do Rio Preto-SP and São Leopoldo-RS, in which R \$30,370,691.08 from 2008 to 2010 and R $\$ 18,770,339$ were spent on these hospitalizations. , 94 from 2003 to 2012, respectively.10,12 Given these data, it appears that an effective and resolute PHC would be able to reduce expenditures with ICSAP, favoring the directing of this capital to deficient areas of the health region and consequently improving health. health care for the population.

Although the information found regarding the ICSAP in Pinheiro is consistent with several Brazilian studies, it is worth highlighting some limitations regarding the instrument used: the AIH-SUS are subject to erroneous information, such as incorrect diagnoses, classification problems regarding the use of the ICD-10 and double or triple counting for the same patient, since the system does not report readmissions. Although there was an increase in FHS coverage in Pinheiro - MA during the period studied, the high frequency of ICSAP in this municipality was evidenced, reaffirming the role of this indicator as an instrument for assessing the PHC's resolving capacity and accessibility. It is hoped that the information produced here will serve as a stimulus for further in-depth studies on possible factors, such as social determinants, that are directly influencing the high rates of ACSC in Pinheiro - MA. In addition, it is of paramount importance that city managers develop projects and policies aimed at restructuring PHC and the health and socioeconomic needs of the local population, so that they can directly impact the occurrence of hospitalizations for conditions sensitive to primary care and quality of life of the population.

\section{References}

1. Santos LPR, Castro ALB, Dutra VGP, Guimarães RM (2018) Internações por condições sensíveis à atenção primária à saúde, 2008-2015: uma análise do impacto da expansão da ESF na cidade do Rio de Janeiro. Cad Saúde Colet 26(2): 178-183.

2. (2011) Ministério da Saúde. Portaria no 2.488, de 21 de outubro de 2011. Aprova a Política Nacional de Atenção Básica, estabelecendo a revisão de diretrizes e normas para a organização da Atenção Básica, para a Estratégia Saúde da Família (ESF) e o Programa de Agentes Comunitários de Saúde (PACS) [Internet]. Diário Oficial da União, Brasília (DF) 1: 48-55.

3. Mendonça SS, Albuquerque EC (2012) Perfil das internações por condições sensíveis à atenção primária em Pernambuco, 2008 a 2012. Epidemiol Serv Saúde [Internet]. jul-set 23(3): 463-474.

4. Brasil VP, Costa JSD (2016) Hospitalizações por condições sensíveis à atenção primária em Florianópolis, Santa Catarina: estudo ecológico de 2001 a 2011. Epidemiol Serv Saúde 25(1): 75-84.

5. Santos BV, Lima DS, Fontes CJF (2019) Internações por condições sensíveis à atenção primária no estado de Rondônia: estudo descritivo do período 2012-2016. Epidemiol Serv Saúde 28(1): 1-12.

6. Arruda JS, Costa JSD (2017) Internações por condições sensíveis à atenção primária em Novo Hamburgo, Rio Grande do Sul. Rev Bras Med Fam Comunidade 12(39): 1-11.

7. Sousa NP, Rehem TCMSB, Santos WS, Santos CE (2016) Internações sensíveis à atenção primária à saúde em hospital regional do Distrito Federal. Rev Bras Enferm [Internet] 69(1): 118-125.

8. (2008) Ministério da Saúde. Portaria no 221, de 17 de abril de 2008. Publica a lista brasileira de internações por condições sensíveis à atenção primária Seção 1:70.

9. Nedel FB, Facchini LA, Mateo MM, Vieira LAS, Thumé E (2008) Programa de Saúde da Família e condições sensíveis à atenção primária, Bagé (RS). Rev Saúde Pública 42(6): 1041-1052.

10. Morimoto T, Costa JSD (2019) Análise descritiva dos gastos com internações por condições sensíveis à atenção primária. Cad Saúde Colet 27(3): 295-300.

11. Campos AZ, Theme Filha MM (2019) Internações por condições sensíveis à atenção primária em Campo Grande, Mato Grosso do Sul, Brasil, 2000 a 2009. Cad Saúde Pública 28(5): 845-855.

12. Ferreira JBB, Borges MJG, Santos LL, Forster AC (2014) Internações por condições sensíveis à atenção primária à saúde em uma região de saúde paulista, 2008 a 2010. Epidemiol Serv Saúde 23(1): 45-56.

13. Pazó RG, Frauches DO, Molina MCB, Cade NV (2017) Panorama das internações por condições sensíveis à atenção primária no Espírito Santo, Brasil 2000 a 2014. Rev Bras Med Fam Comunidade 12(39): 1-12.

14. Moura BLA, Cunha RC, Aquino R, Medina MG, Mota ELA, et al. (2010) Principais causas de internação por condições sensíveis à atenção primária no Brasil: uma análise por faixa etária e região. Rev Bras Saúde Matern Infant 10(Supl 1): 83-91.

15. (2017) Instituto Brasileiro de Geografia e Estatística. Panorama. Rio de Janeiro: IBGE, Brazil.

16. Cardoso CS, Pádua CM, Rodrigues Jr AA, Guimarães DA, Carvalho SF, et al. (2013) Contribuição das internações por condições sensíveis à atenção primária no perfil das admissões pelo sistema público de saúde. Rev Panam Salud Publica 34(4): 227-234. 
17. Lima RCDSM, Gama MEA, Lima RDSM (2019) Condições Sensíveis à Atenção Primária em Hospital de Referência Pediátrica no Maranhão. Rev Pesq Saúde18(2): 97-101.

18. Albuquerque MGA (2015) Análise das Internações por Condições Sensíveis à Atenção Primária (ICSAP) no Município de São Luís nos anos de 2002 e 2012 [dissertação] [Internet]. São Luís (MA): Universidade Federal do Maranhão. Brazil.

19. (2019) Ministério da Saúde(BR) Cadastro Nacional dos Estabelecimentos de Saúde do Brasil. Departamento de Informação e Informática do SUS Consulta estabelecimento - identificação Brasília: Ministério da Saúde, Brazil.

20. (2019) Ministério da Saúde (BR). Cobertura da Atenção Básica [Internet]. Brasília: Ministério da Saúde; c2017, Brazil.

21. Alfradique ME, Bonolo PF, Dourado I, Lima Costa MF, Macinko J, et al. (2009) Internações por condições sensíveis à atenção primária: a construção da lista brasileira como ferramenta para medir o desempenho do sistema de saúde (Projeto ICSAPBrasil). Cad Saúde Pública 25(6): 1337-1349.

22. Rodrigues Bastos RM, Campos EMS, Ribeiro LC, Firmino RUR Bustamante Teixeira MT (2013) Internações por condições sensíveis

\section{ISSN: 2574-1241}

DOI: $10.26717 /$ BJSTR.2020.31.005031

Beatriz Ferreira Feitosa. Biomed J Sci \& Tech Res

(c) (P) This work is licensed under Creative

Submission Link: https://biomedres.us/submit-manuscript.php à atenção primária em município do sudeste do Brasil. Rev Assoc Med Bras (2): 120-127.

23. Zarlotti C, Scudese E, Senna GW, Tonini T, Lopes TS, et al. (2019) Internações por condições sensíveis à atenção primária após a implantação da estratégia saúde da família no município de Petrópolis/ RJ. Rev Fundam Care Online 9(3): 811-817.

24. Rehem TCMSB, Oliveira MRF, Amaral TCL, Ciosak SI, Egry EY (2013) Internações por Condições Sensíveis à Atenção Primária em uma metrópole brasileira. Rev Esc Enferm USP 47(4): 884-890.

25. Magalhães ALA, Morais Neto OL (2017) Desigualdades intraurbanas de taxas de internações por condições sensíveis à atenção primária na região central do Brasil. Ciênc Saúde Colet 22(6): 2049-2062.

26. Pitilin EB, Gutubir D, Molena Fernandes CA, Pelloso SM (2015) Internações sensíveis à atenção primária específicas de mulheres. Ciênc Saúde Colet 20(2): 441-448.

27. Pereira EAM (2018) Internações de idosos por condições sensíveis à atenção primária no nordeste brasileiro, 2008 a 2017 [Internet]. Vitória de Santo Antão (PE): Universidade Federal de Pernambuco, Brazil.

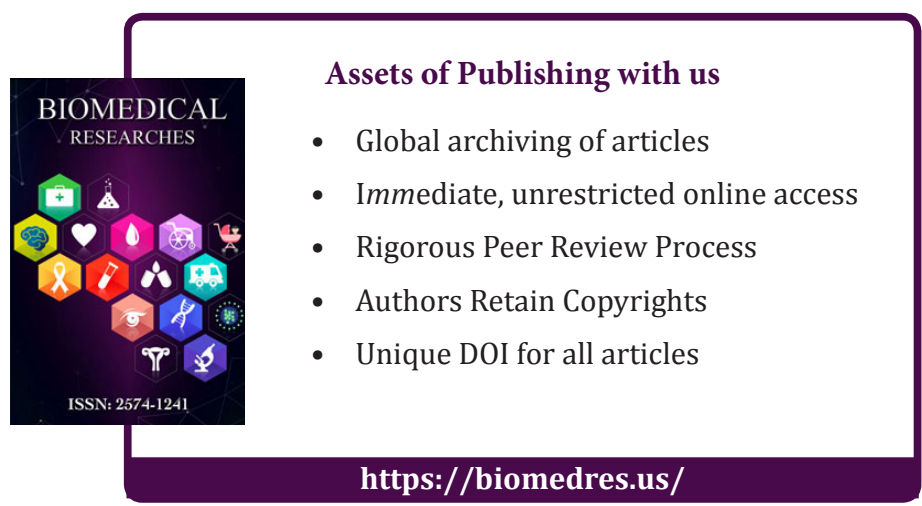

